\title{
Concurrent estimation of lamivudine, tenofovir disoproxil fumarate, and efavirenz in blended mixture and triple combination tablet formulation by a new stability indicating RP-HPLC method
}

\author{
Ramreddy Godela ${ }^{1,2^{*}}$ (D) Vijayalaxmi Kammari ${ }^{3}$, Sowjanya Gummadi ${ }^{1}$ and Durgaprasad Beda ${ }^{2}$
}

\begin{abstract}
Background: An easy, defined, rapid, and accurate reverse phase high-performance liquid chromatography method was developed and subsequently validated for the concurrent estimation of lamivudine, efavirenz, and tenofovir disoproxil fumarate in their pure blend and combined tablet formulation. An efficient and appropriate separation of the three analytes was attained with Zorbax eclipse XDB-Phenyl column, with a mobile phase of methanol: buffer $(0.1 \% \mathrm{v} / \mathrm{v}$ formic acid in water) $(73: 27 \mathrm{v} / \mathrm{v})$ at a flow rate of $1 \mathrm{~mL} / \mathrm{min}$ and isocratic elution by using $260 \mathrm{~nm}$ as detection wavelength. Equal ratio of acetonitrile and water was used as diluent.

Results: The retention times of lamivudine, tenofovir disoproxil fumarate, and efavirenz were found at 2.6, 4.4, and 5.9 min respectively. The linear response for lamivudine, tenofovir disoproxil fumarate, and efavirenz was in the range of $15.0-45.0 \mu \mathrm{g} / \mathrm{mL}, 15.0-45.0 \mu \mathrm{g} / \mathrm{mL}$, and $20.0-60.0 \mu \mathrm{g} / \mathrm{mL}$ respectively. The method validation was done in accordance to $\mathrm{ICH}$ guidelines and all validation parameters in compliance with $\mathrm{ICH}$ standards. The degradants produced by stress testing were well resolved from the peaks of active analytes, which stipulates the stabilityindicating property of the method.

Conclusion: The method has the ability to separate lamivudine, efavirenz, and tenofovir disoproxil fumarate concurrently in blended powder and their combined tablet. All degradants produced by application of stress conditions were separated with high resolution and determined with good sensitivity that ensures the stability-indicating property of the method. Thus, the projected method has high probability to adopt in the pharmaceutical industrial sector.
\end{abstract}

Keywords: Lamivudine, Efavirenz, Tenofovir disoproxil fumarate, Stress testing, Stability indicating, Isocratic elution

\footnotetext{
* Correspondence: ramreddy.godela@gmail.com

'Department of Pharmacy, GITAM Deemed to be University, Visakhapatnam,

India

${ }^{2}$ Department of Pharmaceutical Analysis, Bhaskar Pharmacy College,

Hyderabad, India

Full list of author information is available at the end of the article
}

\section{Springer Open}

(c) The Author(s). 2021 Open Access This article is licensed under a Creative Commons Attribution 4.0 International License, which permits use, sharing, adaptation, distribution and reproduction in any medium or format, as long as you give appropriate credit to the original author(s) and the source, provide a link to the Creative Commons licence, and indicate if changes were made. The images or other third party material in this article are included in the article's Creative Commons licence, unless indicated otherwise in a credit line to the material. If material is not included in the article's Creative Commons licence and your intended use is not permitted by statutory regulation or exceeds the permitted use, you will need to obtain permission directly from the copyright holder. To view a copy of this licence, visit http://creativecommons.org/licenses/by/4.0/. 


\section{Background}

The antiviral therapy with combination of two or more drugs is a great advancement in the treatment of hepatitis B and human immunodeficiency virus diseases. Multi-drug combination therapy is compliance by the patients due to decreased pill load per day. The three-drug combination of lamivudine (LAM), tinofovir disproxil fumarate (TDF), and efavirez (EVZ) is a competent highly active anti-retroviral therapy which comprise of one non-nucleoside reverse transcriptase inhibitor and two nucleoside reverse transcriptase inhibitor drugs $[1,2]$. LAM, chemically, is 4-amino-1[(2R, 5S)-2-(hydroxyl methyl)-1,3-oxathiolan-5-yl]-1, 2-dihydropyrimidin-2-one [3]. It ceases DNA replication by inhibiting the reverse transcriptase enzyme competitively [4]. TDF, chemically, is 1-(6-aminopurine -9-yl) propan-2 yl] oxymethyl-(propan-2-yl oxycarbonyl oxymethyl) phosphoryl] Oxymethyl propan -2yl carbonate [5]. It is a prodrug of tenofovir, which ceases DNA replication by inhibiting the reverse transcriptase enzyme competitively [6-9]. Chemically EVZ, (4S)-6-chloro-4-(2-cyclopropylethynyl)-4-(trifluoromethyl)-1H-3,1-benzoxazin-2-one, is a nonnucleoside reverse transcriptase inhibitor, which inhibits the DNA polymerase non-competitively $[10,11]$. The chemical structures of LAM, TDF, and EVZ are shown in Fig. 1.

A competent analytical method is important for an analyte to determine alone or in blend with other analytes concurrently. The broad literature search disclosed that a small number of analytical methods like UV and RP-HPLC methods were at hand for determination of LAM. TDF and EVZ individually and in combined dosage form [3, 5, 12-16]. In addition to those methods,<smiles>Cc1ccn([C@H]2CS[C@@H](CO)O2)c(=O)n1</smiles>

LAMTVUDINE

Molecular formula: $\mathrm{C}_{8} \mathrm{H}_{11} \mathrm{~N}_{3} \mathrm{O}_{3} \mathrm{~S}$

Molecular weight: $229.26 \mathrm{~g} / \mathrm{mol}$<smiles>O=C1Nc2ccc(Cl)cc2C(C#CC2CC2)([Ge](F)(F)F)O1</smiles>

Efavirenz

Molecular formula: $\mathrm{C}_{14} \mathrm{H}_{9} \mathrm{ClF}_{3} \mathrm{NO}_{2}$ Molecular weight: $315.675 \mathrm{~g} / \mathrm{mol}$<smiles>CC(C)OC(=O)OCO[P@](=O)(CO[C@@H](C)Cn1cnc2c(N)ncnc21)OC(=O)OC(C)C</smiles><smiles>O=C(O)C=CC(=O)O</smiles>

Tinofovir disproxil fumarate

Molecular formula: $\mathrm{C}_{10} \mathrm{H}_{30} \mathrm{~N}_{5} \mathrm{O}_{10} \mathrm{P}$

Molecular weight: $519.448 \mathrm{~g} / \mathrm{mol}$

Fig. 1 Chemical structures of LAM, EVZ, and TDF 
Table 1 Different trials

\begin{tabular}{|c|c|c|c|c|c|}
\hline Trial & Column & Buffer & Mobile phase & $\begin{array}{l}\text { Flow } \\
\text { rate } \\
\mathrm{ml} / \mathrm{min}\end{array}$ & Observation \\
\hline 1 & $\begin{array}{l}\text { Zorbax eclipse XDB-Phenyl } \\
(250 \times 4.6 \mathrm{~mm}, 5 \mu \mathrm{m})\end{array}$ & $\begin{array}{l}0.1 \%(V N) \\
\text { formic acid }\end{array}$ & $\begin{array}{l}\text { Buffer: ACN (50:50 } \\
\text { v/v) }\end{array}$ & 1.23 & Peak tailing (1.3) and long retention time (9.52 min) of EVZ \\
\hline 2 & Zorbax SB C8 (100×4.6mm, 5um) & $\begin{array}{l}0.1 \%(V N) \\
\text { formic acid }\end{array}$ & $\begin{array}{l}\text { Buffer: ACN (35:65 } \\
\text { v/v) }\end{array}$ & 1.23 & Resolution (1.5) was not good between LAM and TDF \\
\hline 3 & Inertsil C8 (150×4.6mm, 5um) & $\begin{array}{l}0.1 \%(V N) \\
\text { formic acid }\end{array}$ & $\begin{array}{l}\text { Buffer: ACN }(35: 65 \\
\text { v/v) }\end{array}$ & 1.23 & Resolution (1.6) was not good between LAM and TDF \\
\hline 4 & $\begin{array}{l}\text { Zorbax eclipse XDB-phenyl } \\
(250 \times 4.6 \mathrm{~mm}, 5 \mu \mathrm{m})\end{array}$ & $\begin{array}{l}0.1 \%(V N) \\
\text { formic acid }\end{array}$ & $\begin{array}{l}\text { Buffer: ACN }(30: 70 \\
\text { v/v) }\end{array}$ & 1.23 & $\begin{array}{l}\text { Resolution was good, but retention time of EFV was long } \\
(8.056 \mathrm{~min})\end{array}$ \\
\hline 5 & Phenyl XDB (250×4.6mm, 5um) & $\begin{array}{l}0.1 \%(V N) \\
\text { formic acid }\end{array}$ & $\begin{array}{l}\text { Buffer: methanol } \\
(50: 50 \mathrm{v} / \mathrm{v})\end{array}$ & 1 & Long retention time of EFV (7.201 min) \\
\hline 6 & Phenyl XDB (250×4.6mm, 5um) & $\begin{array}{l}0.1 \%(V N) \\
\text { formic acid }\end{array}$ & $\begin{array}{l}\text { Buffer: methanol } \\
(27: 73 \mathrm{v} / \mathrm{v})\end{array}$ & 1 & $\begin{array}{l}\text { Good resolution between LAM and TDF (9.13), TDF and EVZ } \\
\text { (7.55), and less retention time (LAM- } 2.6 \mathrm{~min} \text {, TDF- } 4.4 \mathrm{~min} \text {, } \\
\text { EVZ-5.9 min) }\end{array}$ \\
\hline
\end{tabular}

$X D B$ extra dense bonding, $A C N$ acetonitrile, EFV efavirenz

few RP-HPLC methods were described for determination of LAM, TDF with dolutegravir, and other antiviral agents [17-21]. As of yet, a competent stabilityindicating RP-HPLC method was not available for the concurrent evaluation of LAM, EVZ, and TDF in pure blend and combined tablet formulation. Hence, research attempts have been done to develop an efficient, highly responsive and cost-effective RP-HPLC method to estimate the percentage purity and to evaluate the stability of LAM, EVZ, and TDF in blended bulk powder and tablet formulation concurrently. To assure the developed method, validation of the method was done as indicated by Q2R1 guidelines of $\mathrm{ICH}$.

\section{Methods}

\section{Pure drug samples}

Pure and active form of LAM (99.4\%), EVZ (99.4\%), and TDF (99.3\%) were procured as gift samples from Aurobindo Pharma, Hyderabad.

\section{Formulation}

Film-coated tablet dosage forms (Symfi Lo is a fixeddose combination product containing $400 \mathrm{mg}$ of EVZ,
$300 \mathrm{mg}$ of LAM, and $300 \mathrm{mg}$ of TDF) were purchased from local pharmacy in Hyderabad.

\section{Chemicals and reagents}

All HPLC grade and analytical grade solvents were purchased by local distributor of Merck India.

\section{Instrument specifications}

The method was done by using WATERS HPLC (2695model, PDA detector, and the Empower 2 solution software). In addition, an analytical balance (Denver instrument, TB-215D), a digital $\mathrm{pH}$ meter (MEZARIT), and water (Milli-Q) were used. Forty-five micrometers povidone filters were used to filter all the solutions and the solvents before introduced into the instrument.

\section{Chromatographic method conditions}

An efficient and appropriate separation of the three analytes was done with Zorbax eclipse XDB-Phenyl (250 x $4.6 \mathrm{~mm}, 5 \mu)$ column, using a mobile phase consist of methanol: buffer $(0.1 \% \mathrm{v} / \mathrm{v}$ formic in water) $(73: 27 \mathrm{v} / \mathrm{v})$ at a flow rate of $1 \mathrm{~mL} / \mathrm{min}$ and a detection wavelength of

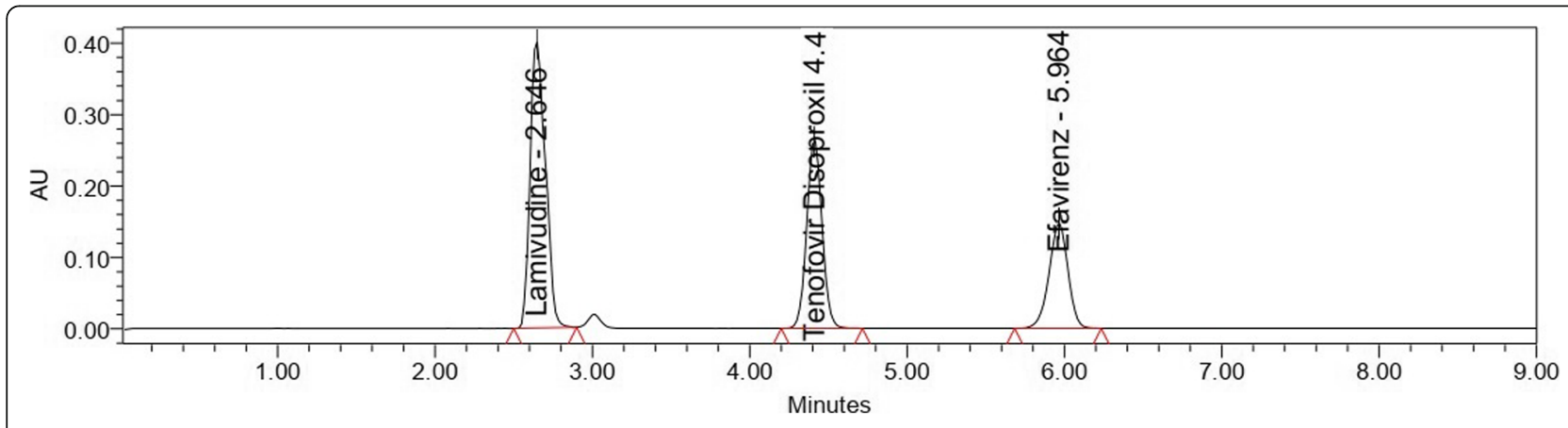

Fig. 2 Optimized chromatogram of the method 
Table 2 Results of system suitability parameters of standard solution

\begin{tabular}{lllllll}
\hline & Parameter & tR & Area & USP tailing & USP plate count & Average resolution \\
\hline LAM & Mean & 2.65 & $2,702,001$ & 1.21 & 2863.8 & - \\
& SD & 0.01 & 9637.52 & 0.01 & 27.23 & 0.95 \\
TDF & \%RSD & 0.24 & 0.35 & 1.0 & 9659.2 & 9.13 \\
& Mean & 4.40 & $1,779,305$ & 1.0 & 152.76 & 1.581 \\
EVZ & SD & 0.01 & 4811.89 & 0.01 & 11737.6 & 7.55 \\
& \%RSD & 0.28 & 0.27 & 0.52 & 127.73 & 1.08 \\
\\
Acceptance limit & Mean & 5.93 & $1,237,753$ & 0.94 & $>2000$ & $>2$
\end{tabular}

$S D$ standard deviation, \%RSD relative standard deviation

$260.0 \mathrm{~nm}$. Equal ratio of acetonitrile and water was used as diluents.

\section{Preparation of standard solution}

One hundred milligrams of LAM, 100.0mg of TDF, and $133.3 \mathrm{mg}$ of EVZ pure powders were accurately weighed and dissolved with diluent in a $100-\mathrm{mL}$ volumetric flask. One milliliter of the above solution was diluted to $10 \mathrm{~mL}$. Three milliliters of the resultant solution was further diluted to $10 \mathrm{~mL}$ to get a concentration of $30.0 \mu \mathrm{g} / \mathrm{mL}$, $40.0 \mu \mathrm{g} / \mathrm{mL}$, and $30.0 \mu \mathrm{g} / \mathrm{mL}$ for LAM, EVZ, and TDF respectively.

\section{Preparation of sample solution}

The crushed tablet powder equivalent to $100 \mathrm{mg}$ of LAM, 100mg of TDF, and 133.3mg of EVZ pure powders was accurately weighed and dissolved with diluent in 100-mL volumetric flask. One milliliter of the above solution was diluted to $10 \mathrm{~mL}$. Three milliliters of the resultant solution was further diluted to $10 \mathrm{~mL}$ to get a concentration of $30.0 \mu \mathrm{g} / \mathrm{mL}, 40.0 \mu \mathrm{g} / \mathrm{mL}$, and $30.0 \mu \mathrm{g} / \mathrm{mL}$ for LAM, EVZ, and TDF respectively.

\section{Method validation}

Validation is written evidence that provides assurance of the method or process with high degree level. To validate analytical method, Q2R1 guidelines of the $\mathrm{ICH}$ were taken into consideration.

\section{System suitability test}

The system suitability test of the present method was established by injecting standard solution in 6 consecutive injections, and the parameters such as percentage relative standard deviation (\%RSD), tailing factor $(\mathrm{T})$, resolution $(\mathrm{R})$, and number of theoretical plates $(\mathrm{N})$ were assessed for the chromatograms thus attained.

\section{Linearity}

The linearity of an analytical method signifies the direct proportional relationship between experimental results and the given concentrations. It was established for the solutions having concentrations ranging from 15.0 to $45.0 \mu \mathrm{g} / \mathrm{mL}$ of both LAM and TDF and 20.0 to $60.0 \mu \mathrm{g} /$ $\mathrm{mL}$ of EVZ. A calibration curve was plotted between concentration and peak area to determine regression coefficient $\left(R^{2}\right)$.

\section{Precision}

The precision of the method expresses the close agreement between the observed responses of homogenous samples on multiple sampling at identical conditions.

Table 3 Concentration and peak areas of linearity level solution of LAMI, TDF, and EVZ

\begin{tabular}{|c|c|c|c|c|c|c|}
\hline \multirow[t]{2}{*}{ \%Level } & \multicolumn{2}{|l|}{ LAM } & \multicolumn{2}{|l|}{ TDF } & \multicolumn{2}{|l|}{ EVZ } \\
\hline & Concentration $(\mu \mathrm{g} / \mathrm{mL})$ & Peak area & Concentration $(\mu \mathrm{g} / \mathrm{mL})$ & Peak area & Concentration $(\mu \mathrm{g} / \mathrm{mL})$ & Peak area \\
\hline 50 & 15.0 & $1,343,818$ & 15.0 & 913,725 & 20.0 & 613,391 \\
\hline 75 & 22.5 & $2,110,176$ & 22.5 & $1,430,523$ & 30.0 & 934,415 \\
\hline 100 & 30.0 & $2,690,079$ & 30.0 & $1,832,027$ & 40.0 & $1,216,978$ \\
\hline 125 & 37.5 & $3,422,954$ & 37.5 & $2,339,804$ & 50.0 & $1,552,558$ \\
\hline 150 & 45.0 & $4,176,437$ & 45.0 & $2,842,257$ & 60.0 & $1,903,481$ \\
\hline \multicolumn{2}{|c|}{ Regression coefficient $\left(R^{2}\right)$} & 0.998 & & 0.998 & & 0.998 \\
\hline
\end{tabular}

$R^{2}$ regression coefficient 


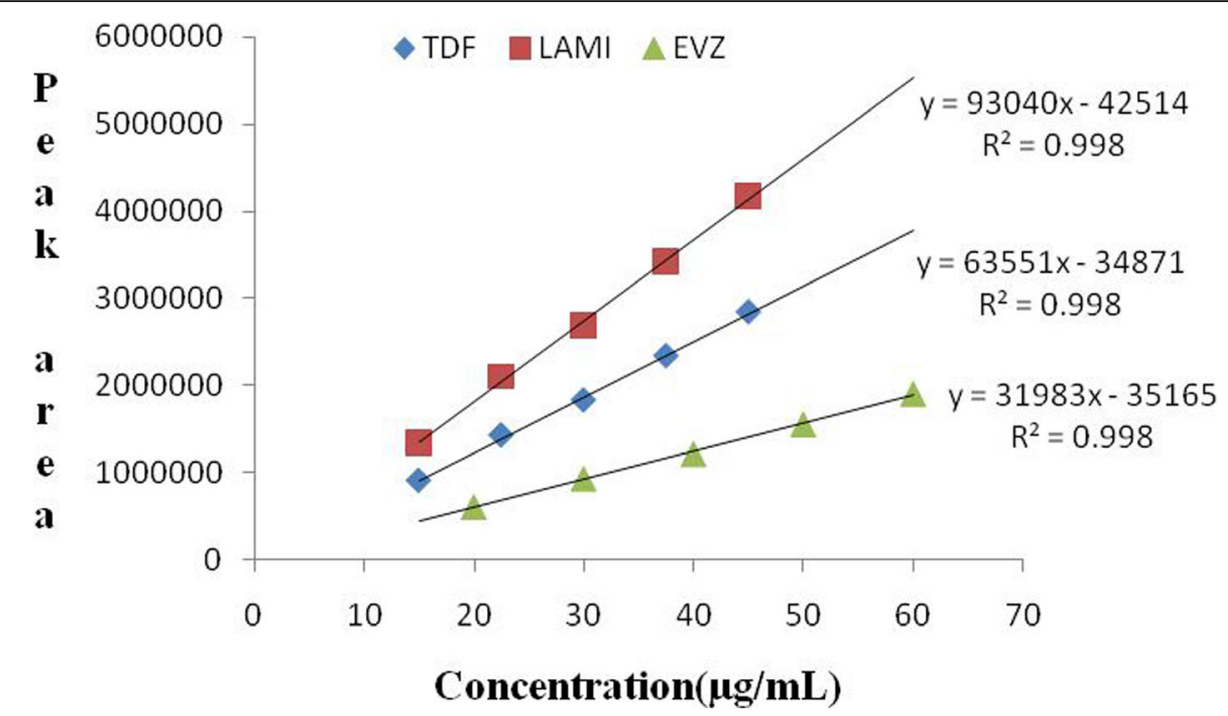

Fig. 3 Linearity curve of LAM, EVZ, and TDF

In general, it can be performed on the same day and on different consecutive days represented as intra-day (repeatability) precision and inter-day precision (intermediate precision) respectively. Repeatability was assessed by injecting standard solution for five times in a single day, and intermediate precision was assessed by injecting same standard solution for two times per day for three successive continuous days. \%RSD values were assessed for peak areas attained in chromatograms.

\section{Accuracy}

Substantially, the accuracy was validated by percentage recovery studies where specified amount of sample solution was spiked into standard solution. In general, spiking can be done at 50,100, and $150 \%$ level concentrations of standard solution. Each level solution was injected for three times. The \% mean recovery of sample at each spiked level was calculated.

\section{Specificity}

Specificity is the ability of the analytical method to assess the analyte of interest in the presence of other substances including degradation products and excipients without interferences. It was performed by introducing consecutive injections of placebo, blank, standard, and placebo mixed with standard. The obtained chromatograms were examined for interference from the peaks of other substances with peaks of analytes to be determined.

\section{Sensitivity}

The LOQ and LOD were reckoned by using the following formulae:

Table 4 Results of percentage recovery

\begin{tabular}{|c|c|c|c|c|c|}
\hline Drug name & $\%$ level & Amount added $(\mu \mathrm{g} / \mathrm{ml})$ & Amount recovered $(\mu \mathrm{g} / \mathrm{ml})$ & $\%$ recovery & Acceptance limit \\
\hline \multirow[t]{3}{*}{ LAM } & 50 & 15.0 & 14.86 & 99.06 & $98.0-102.0 \%$ \\
\hline & 100 & 30.0 & 30.01 & 100.0 & \\
\hline & 150 & 45.0 & 44.9 & 99.7 & \\
\hline \multirow[t]{3}{*}{ TDF } & 50 & 15.0 & 15.0 & 100.0 & \\
\hline & 100 & 30.0 & 29.97 & 99.9 & \\
\hline & 150 & 45.0 & 45.0 & 100.0 & \\
\hline \multirow[t]{3}{*}{ EVZ } & 50 & 20.0 & 19.9 & 99.5 & \\
\hline & 100 & 40.0 & 39.6 & 99.0 & \\
\hline & 150 & 60.0 & 60.2 & 100.3 & \\
\hline
\end{tabular}

The percentage recovery at each percentage level within the acceptable limit 
Table 5 Results of intraday and inter-day precision of standard solution

\begin{tabular}{|c|c|c|c|c|c|c|c|}
\hline \multirow[t]{2}{*}{ Precision } & \multirow[t]{2}{*}{ S.NO } & \multicolumn{2}{|l|}{ LAM } & \multicolumn{2}{|l|}{ TDF } & \multicolumn{2}{|l|}{ EVZ } \\
\hline & & $\overline{t R}$ & Peak area & $\mathrm{tR}$ & Peak area & tR & Peak area \\
\hline \multirow[t]{8}{*}{ Intraday } & 1 & 2.646 & $2,717,067$ & 4.411 & $1,786,776$ & 5.964 & $1,235,921$ \\
\hline & 2 & 2.658 & $2,696,080$ & 4.418 & $1,776,006$ & 5.955 & $1,235,063$ \\
\hline & 3 & 2.642 & $2,704,851$ & 4.396 & $1,780,791$ & 5.924 & $1,240,927$ \\
\hline & 4 & 2.644 & $2,692,168$ & 4.391 & $1,774,513$ & 5.913 & $1,235,911$ \\
\hline & 5 & 2.644 & $2,699,839$ & 4.390 & $1,778,441$ & 5.909 & $1,240,942$ \\
\hline & Mean & 2.647 & $2,702,001$ & 4.401 & $1,779,305$ & 5.933 & $1,237,753$ \\
\hline & SD & 0.01 & 9637.5 & 0.01 & 4811.9 & 0.03 & 2925.3 \\
\hline & $\%$ RSD & 0.24 & 0.36 & 0.29 & 0.27 & 0.42 & 0.24 \\
\hline \multicolumn{8}{|l|}{ Inter-day } \\
\hline \multirow[t]{2}{*}{ Day 1} & 1 & 2.646 & $2,717,067$ & 4.411 & $1,786,776$ & 5.964 & $1,235,921$ \\
\hline & 2 & 2.65 & $2,632,428$ & 4.388 & $1,799,791$ & 5.899 & $1,202,415$ \\
\hline \multirow[t]{2}{*}{ Day 2} & 1 & 2.648 & $2,637,342$ & 4.391 & $1,805,023$ & 5.907 & $1,203,026$ \\
\hline & 2 & 2.652 & $2,647,962$ & 4.398 & $1,812,939$ & 5.917 & $1,209,358$ \\
\hline \multirow[t]{5}{*}{ Day 3} & 1 & 2.65 & $2,641,549$ & 4.398 & $1,806,413$ & 5.914 & $1,205,118$ \\
\hline & 2 & 2.65 & $2,644,845$ & 4.393 & $1,810,105$ & 5.903 & $1,207,765$ \\
\hline & Mean & 2.649 & $2,653,532$ & 4.397 & $1,803,508$ & 5.917 & $1,210,601$ \\
\hline & SD & 0.002 & 31,605 & 0.008 & 9349 & 0.024 & 12,690 \\
\hline & $\%$ RSD & 0.08 & 1.19 & 0.18 & 0.52 & 0.40 & 1.05 \\
\hline
\end{tabular}

$S D$ standard deviation, \%RSD relative standard deviation, $t R$ retention time

$$
\begin{aligned}
& \mathrm{LOD}=3 \times \sigma / S \\
& \mathrm{LOQ}=10 \times \sigma / S
\end{aligned}
$$

where $\sigma$ is the SD of intercept and $S$ is the slope of the linear curve.

\section{Robustness}

Method's robustness was assessed by changing the optimized conditions of the method to a little extent intentionally. In this case, optimized conditions like ratio of the mobile phase $( \pm 1 \mathrm{~mL})$, flow rate of mobile phase $( \pm 0.1 \mathrm{~mL} / \mathrm{min})$, and detection wavelength $( \pm 2 \mathrm{~nm})$ were intentionally altered to a little extent.

\section{Forced degradation studies}

In forced degradation (FD) studies, chemical stability of the analyte can be assessed in the presence of more intensive conditions like acid and alkali hydrolysis, oxidative degradation, and thermal and photo stability as provided by $\mathrm{ICH}$ quality guidelines.

\begin{tabular}{|c|c|c|c|c|c|c|c|}
\hline \multirow[t]{2}{*}{ Variation in parameter } & & \multicolumn{2}{|l|}{ LAM } & \multicolumn{2}{|l|}{ TDF } & \multicolumn{2}{|l|}{ EVZ } \\
\hline & & $\begin{array}{l}\text { \%RSD of } \\
\text { peak area }\end{array}$ & $\begin{array}{l}\text { Plate } \\
\text { count }\end{array}$ & $\begin{array}{l}\text { \%RSD of } \\
\text { peak area }\end{array}$ & $\begin{array}{l}\text { Plate } \\
\text { count }\end{array}$ & $\begin{array}{l}\text { \%RSD of } \\
\text { peak area }\end{array}$ & $\begin{array}{l}\text { Plate } \\
\text { count }\end{array}$ \\
\hline \multirow[t]{2}{*}{ Mobile phase ratio $( \pm 1 \mathrm{ml})$} & $26: 74$ & 1.3 & 2905 & 0.97 & 9659 & 0.67 & 11,823 \\
\hline & $28: 72$ & 1.4 & 2817 & 1.35 & 9253 & 1.60 & 11,742 \\
\hline \multirow[t]{2}{*}{ Flow rate $( \pm 0.1 \mathrm{~mL} / \mathrm{min})$} & $0.9 \mathrm{~mL} / \mathrm{min}$ & 0.52 & 2896 & 0.27 & 9675 & 0.47 & 11,963 \\
\hline & $1.1 \mathrm{~mL} / \mathrm{min}$ & 0.51 & 2841 & 0.24 & 9352 & 0.23 & 11,452 \\
\hline \multirow[t]{3}{*}{ Wavelength $( \pm 2 \mathrm{~nm})$} & 258 & 0.35 & 2831 & 0.27 & 9341 & 0.31 & 11,994 \\
\hline & 262 & 0.36 & 2912 & 0.27 & 9368 & 0.23 & 11,535 \\
\hline & $\%$ RSD & & 1.46 & $\%$ RSD & 1.89 & $\%$ RSD & 1.88 \\
\hline
\end{tabular}

Table 6 Results of robustness of standard solution 
Table 7 Results of forced degradation studies

\begin{tabular}{|c|c|c|c|c|c|c|}
\hline Drug name & Standard & Acid hydrolysis & Base hydrolysis & Oxidative degradation & Photo degradation & Thermal degradation \\
\hline \multicolumn{7}{|c|}{ Peak area of the solution } \\
\hline LAM & $2,717,067$ & $2,434,053$ & $2,578,801$ & $2,616,177$ & $2,694,163$ & $2,679,066$ \\
\hline TDF & $1,786,776$ & $1,641,002$ & $1,472,204$ & $1,753,290$ & $1,758,594$ & $1,776,392$ \\
\hline EVZ & $1,235,921$ & $1,177,547$ & $1,055,922$ & $1,194,572$ & $1,212,763$ & $1,222,960$ \\
\hline \multicolumn{7}{|c|}{$\%$ Degradation } \\
\hline LAM & - & 10.4 & 5.0 & 3.7 & 0.85 & 1.4 \\
\hline TDF & - & 8.1 & 17.6 & 1.87 & 1.58 & 0.6 \\
\hline EVZ & - & 4.7 & 14.5 & 3.34 & 1.87 & 1.0 \\
\hline
\end{tabular}

Percentage degradation was less than $20 \%$ with different stress conditions

\section{Acid and alkali hydrolysis}

Ten milliliters of standard stock solution was mixed with $2 \mathrm{~mL}$ of $0.1 \mathrm{~N} \mathrm{HCl}$ and $2 \mathrm{~mL}$ of $0.1 \mathrm{~N} \mathrm{NaOH}$ separately, reflux the prepared solutions for $2 \mathrm{~h}$ at $70^{\circ} \mathrm{C}$, and kept it aside at room temperature for $24 \mathrm{~h}$. The resultant solutions were neutralized and further diluted in such a way to get a concentration of $30 \mu \mathrm{g} /$
$\mathrm{mL}, 40 \mu \mathrm{g} / \mathrm{mL}$, and $30 \mu \mathrm{g} / \mathrm{mL}$ for LAM, EVZ, and TDF respectively.

\section{Oxidative degradation}

Ten milliliters of standard stock solution was mixed with $2 \mathrm{~mL}$ of $3 \%$ hydrogen peroxide and reflux the prepared solutions for $2 \mathrm{~h}$ at $70{ }^{\circ} \mathrm{C}$, and kept it aside

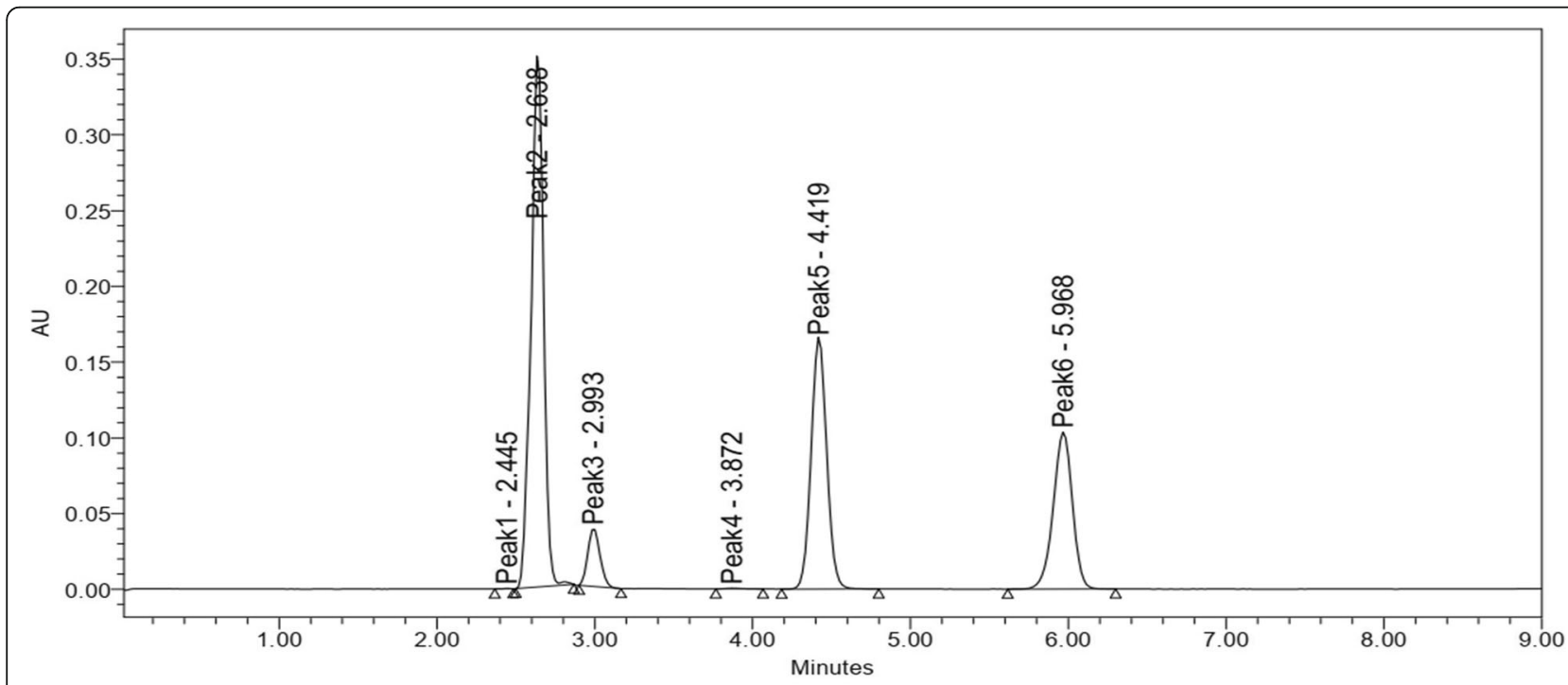

\begin{tabular}{|c|c|c|c|}
\hline Peak & tR & Peak area & Resolution (R) \\
\hline Peak1 & 2.445 & 940 & 2.1 \\
\hline Peak2 (Lamivudine) & 2.638 & 2434053 & 2.9 \\
\hline Peak3 & 2.993 & 206629 & 4.2 \\
\hline Peak4 & 3.872 & 3825 & 2.6 \\
\hline $\begin{array}{c}\text { Peak5 } \\
\text { (Tenofovir disoproxil fumarate) }\end{array}$ & 4.419 & 1641002 & 7.51 \\
\hline Peak6 (Efavirez) & 5.968 & 1177547 & \\
\hline
\end{tabular}

Fig. 4 Chromatogram of acid degradation 
for $24 \mathrm{~h}$ and further diluted in such a way to get a concentration of $30 \mu \mathrm{g} / \mathrm{mL}, 40 \mu \mathrm{g} / \mathrm{mL}$, and $30 \mu \mathrm{g} / \mathrm{mL}$ for LAM, EVZ, and TDF respectively.

\section{Thermal degradation}

The standard stock solution was placed in hot air oven at $80^{\circ} \mathrm{C} / 75 \%$ relative humidity for $24 \mathrm{~h}$. One milliliter of the above exposed solution was further diluted in such a way to get a concentration of $30 \mu \mathrm{g} / \mathrm{mL}, 40 \mu \mathrm{g} / \mathrm{mL}$, and $30 \mu \mathrm{g} / \mathrm{mL}$ for LAM, EVZ, and TDF respectively.

\section{Photo degradation}

The standard stock solution was in ultraviolet chamber at $254.0 \mathrm{~nm}$ for $24 \mathrm{~h}$. One milliliter of above exposed solution was further diluted in such a way to get a concentration of $30 \mu \mathrm{g} / \mathrm{mL}, 40 \mu \mathrm{g} / \mathrm{mL}$, and $30 \mu \mathrm{g} / \mathrm{mL}$ for LAM, EVZ, and TDF respectively.

The above mentioned FD solutions were injected and computed for the percentage degradation of LAM, EVZ, and TDF. As per most of the researcher's suggestions, the considerable degradation of analyte is around 20\% for the validation of stability-indicating HPLC method.

\section{Assay}

The assays of the LAM, EVZ, and TDF in commercial tablets were determined by injecting sample solution.

\section{Results}

The foremost step in the method development is to determine the solubility of the analyte. It was observed that LAM and TDF were freely soluble in water and acetonitrile and slightly soluble in methanol, and EVZ was soluble in methanol and acetonitrile and insoluble in water. On the basis of solubility of LAM, EVZ, and TDF, water and acetonitrile in 1:1 ratio was chosen as diluent.

\section{Method optimization}

Method optimization was completed after several trials. In this research, several trials have been done with different columns, mobile phases, and flow rates to attain a method with good resolution (R), N, T, and \% RSD. At last, a method with Zorbax eclipse XDB-Phenyl column, with a mobile phase of methanol: buffer $(0.1 \% \mathrm{v} / \mathrm{v}$ formic in water) $(73: 27 \mathrm{v} / \mathrm{v})$ at a flow rate of $1 \mathrm{~mL} / \mathrm{min}$ and detection wavelength of $260.0 \mathrm{~nm}$ was elected as optimized

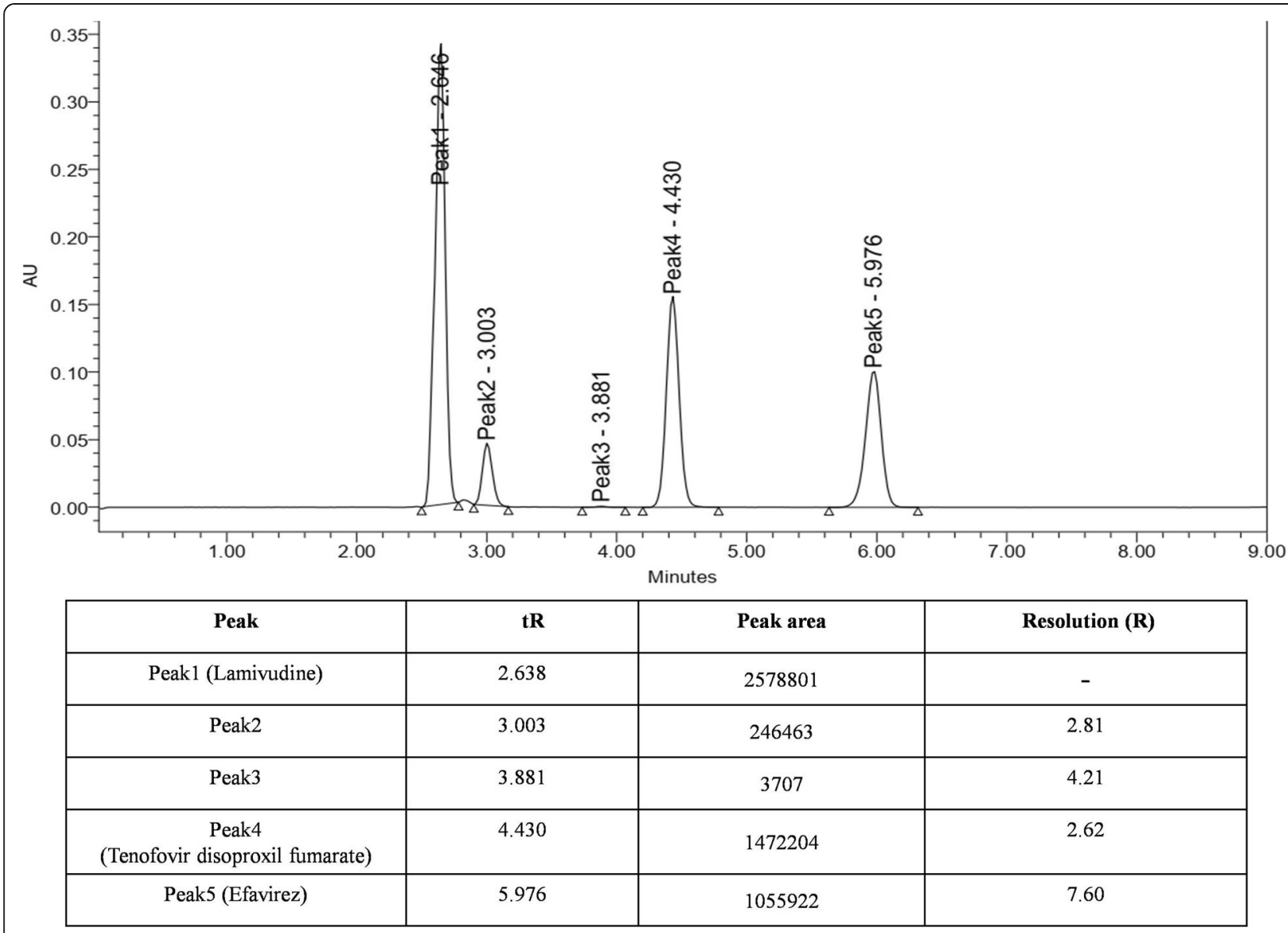

Fig. 5 Chromatogram of base degradation 
conditions (trial 6). The different trial conditions and their observation are shown in Table 1 . The optimized chromatogram is shown in Fig. 2.

\section{Method validation}

\section{System suitability}

All parameters of the system suitability test were in compliance with standards of ICH (Table 2).

\section{Linearity}

The linear response of the LAM, TDF, and EVZ were in the series of 15.0 to $45.0 \mu \mathrm{g} / \mathrm{mL}, 15.0$ to $45.0 \mu \mathrm{g} / \mathrm{mL}$, and 20.0 to $60.0 \mu \mathrm{g} / \mathrm{mL}$. Linearity was confirmed by calculating $R^{2}$ value from linear plot constructed between concentration and peak area (Table 3 , Fig. 3 ). The $R^{2}$ values of the three analytes were in compliance with $\mathrm{ICH}$ limits.

\section{Accuracy}

The mean percentage recovery of the all the three analytes in spiked solutions of three specified levels were found to be $100 \% \pm 2$ (Table 4), which illustrates that method was highly accurate as it is in compliance with standards laid down by $\mathrm{ICH}$.

\section{Precision}

\%RSD value of the peak areas of the LAM, EVZ, and TDF in replicate injections of the standard solution was assessed as $\leq 2$ (Table 5), which describes that the current method was highly precise.

\section{Sensitivity}

The detection limit (LOD) and quantification limit (LOQ) responses were assessed to be $1.9 \mu \mathrm{g} / \mathrm{ml}$ and $5.8 \mu \mathrm{g} / \mathrm{ml}$ for LAM, $1.7 \mu \mathrm{g} / \mathrm{mL}$ and $5.2 \mu \mathrm{g} / \mathrm{mL}$ for TDF, and $2.3 \mu \mathrm{g} / \mathrm{mL}$ and $6.8 \mu \mathrm{g} / \mathrm{mL}$ for EVZ respectively.

\section{Robustness}

Intentional changes in optimized procedure conditions to little extent could not influence the system suitability parameter results which were in compliance with the standards of ICH (Table 6), stipulates that the method has considerable robustness.

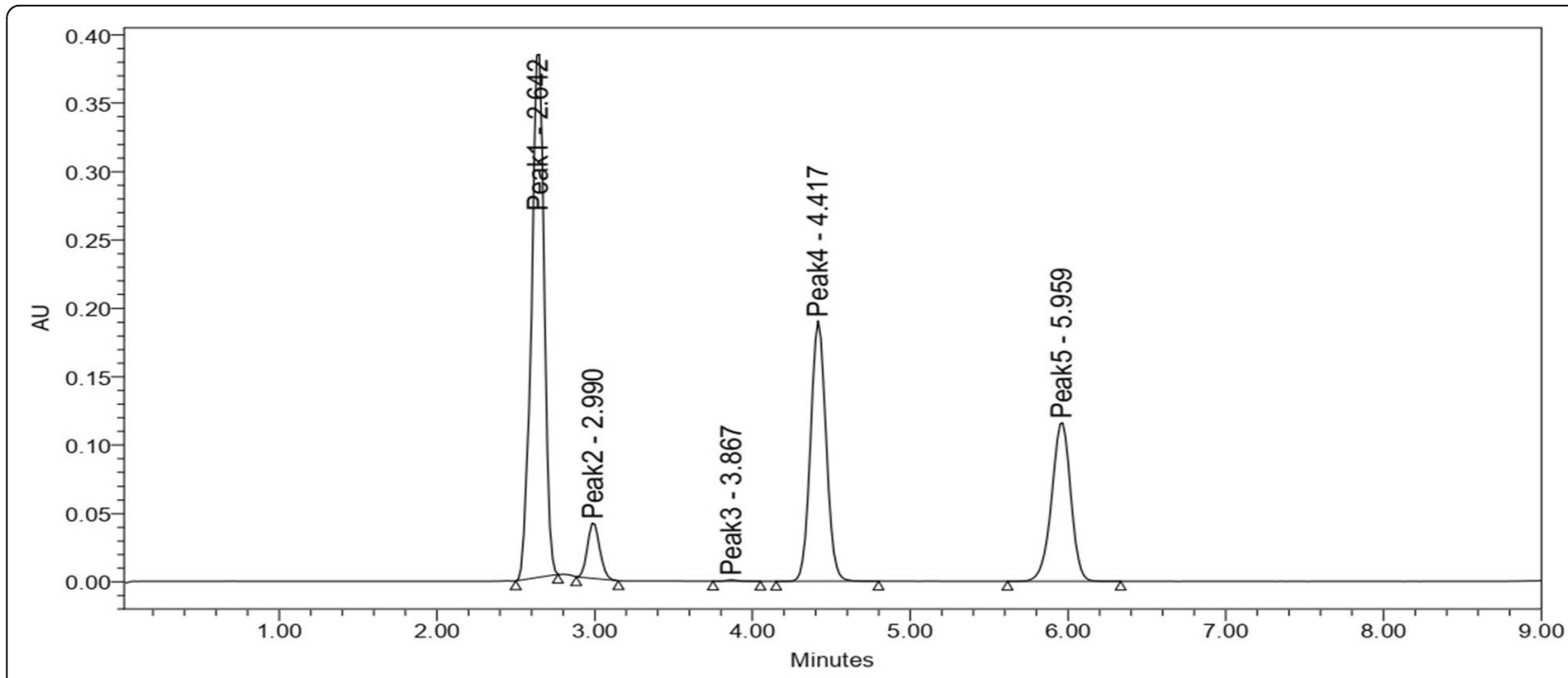

\begin{tabular}{|c|c|c|c|}
\hline Peak & tR & Peak area & Resolution (R) \\
\hline Peak1 (Lamivudine) & 2.642 & 2616177 & 2.80 \\
\hline Peak2 & 2.990 & 221450 & 4.25 \\
\hline Peak3 & 3.867 & 5547 & 2.59 \\
\hline $\begin{array}{c}\text { Peak4 } \\
\text { (Tenofovir disoproxil fumarate) }\end{array}$ & 4.417 & 1753290 & 7.62 \\
\hline Peak5 (Efavirez) & 5.959 & 1194572 & 2 \\
\hline
\end{tabular}

Fig. 6 Chromatogram of oxidative degradation 


\section{Forced degradation}

The percentage degradations of the three analytes in stressed solutions are given in Table 7. Acid hydrolysis, alkali hydrolysis, oxidative degradation, photo degradation, and thermal chromatograms were mentioned in Figs. 4, 5, 6, 7, and 8 respectively. Those results were stipulating the stability-indicating property of the method.

\section{Assay}

The percentage assay of the LAM, EVZ, and TDF in the combined tablet form were within $100 \% \pm 15$ limit (Table 8), which are in compliance with standards of $\mathrm{ICH}$.

\section{Discussion}

Many RP-HPLC procedures were available for simultaneous determination of LAM, EVZ, and TDF in combined tablets [12-19]. But no RP-HPLC method was subsisted with a simple solvent system, and less retention time existed. Along with those, the reported methods have drawbacks like less sensitivity and without FD studies. Therefore, endeavored to ascertain a stability-indicating method with simple solvent system [methanol $0.1 \%$ formic acid $(73: 27 \mathrm{v} /$ v)] and less RT (less than $6 \mathrm{~min}$ ). The RT of the analytes was less than the previously subsisted method which is regarded as cost-effective due to decrease in elution time and volume of solvent to be consumed. Therefore, analysis of sample time is reduced, and more number of samples can be analyzed.

The developed method was validated as per Q2R1 guidelines of $\mathrm{ICH}$. The developed method has good LOD and LOQ of $1.9 \mu \mathrm{g} / \mathrm{ml}$ and $5.8 \mu \mathrm{g} / \mathrm{ml}$ for LAM, $1.7 \mu \mathrm{g} / \mathrm{mL}$ and $5.2 \mu \mathrm{g} / \mathrm{mL}$ for $\mathrm{TDF}$, and $2.3 \mu \mathrm{g} / \mathrm{mL}$ and $6.8 \mu \mathrm{g} / \mathrm{mL}$ for EVZ respectively. Those values revealed that the current method has good sensitivity than the previously reported methods. The FD studies helped in determination of the amount of the drug degraded by application of different stressed conditions, which represents the stability-indicating property of the method. The developed method validation parameters were in compliance with Q2R1 specifications of $\mathrm{ICH}$.

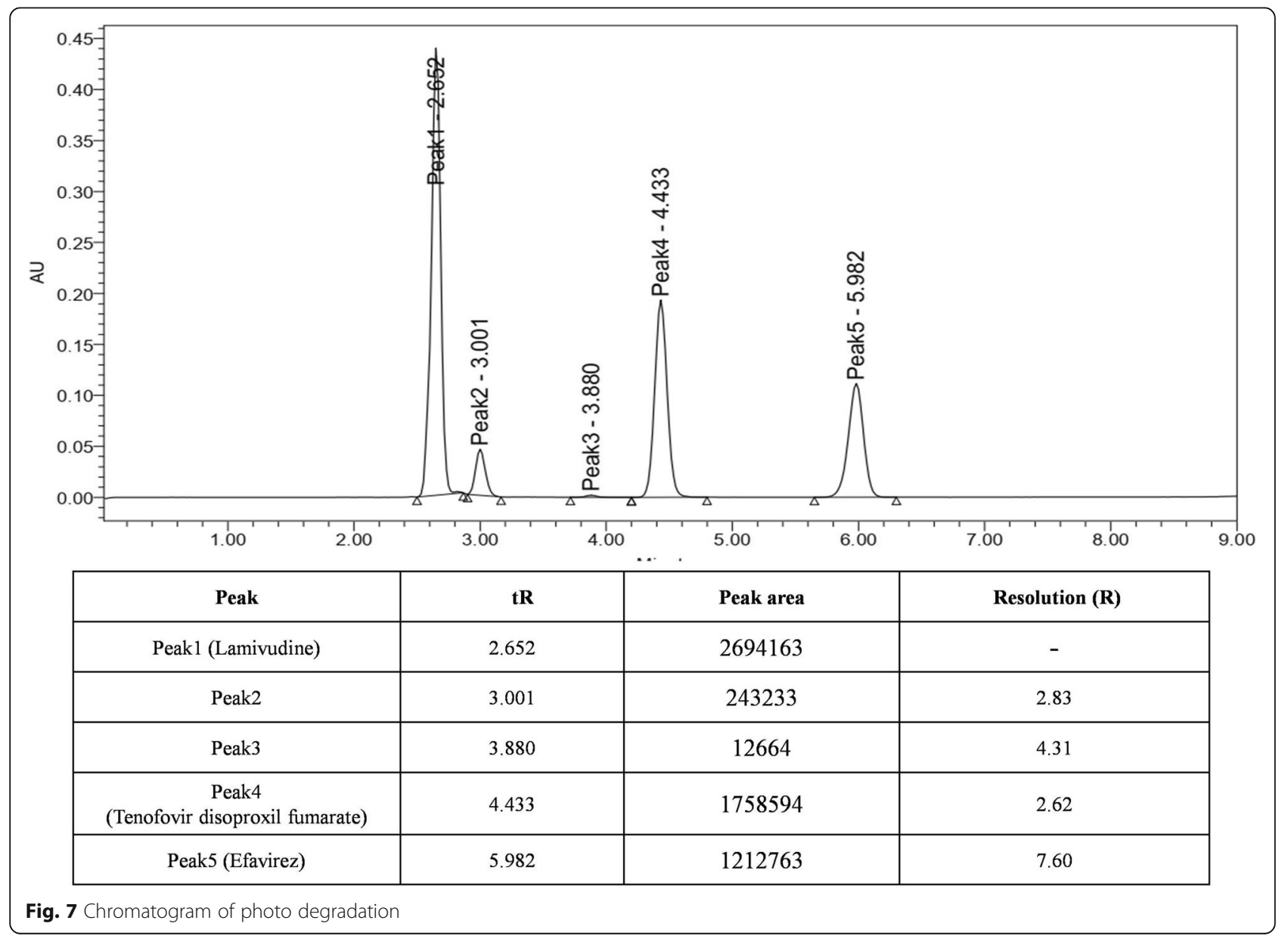




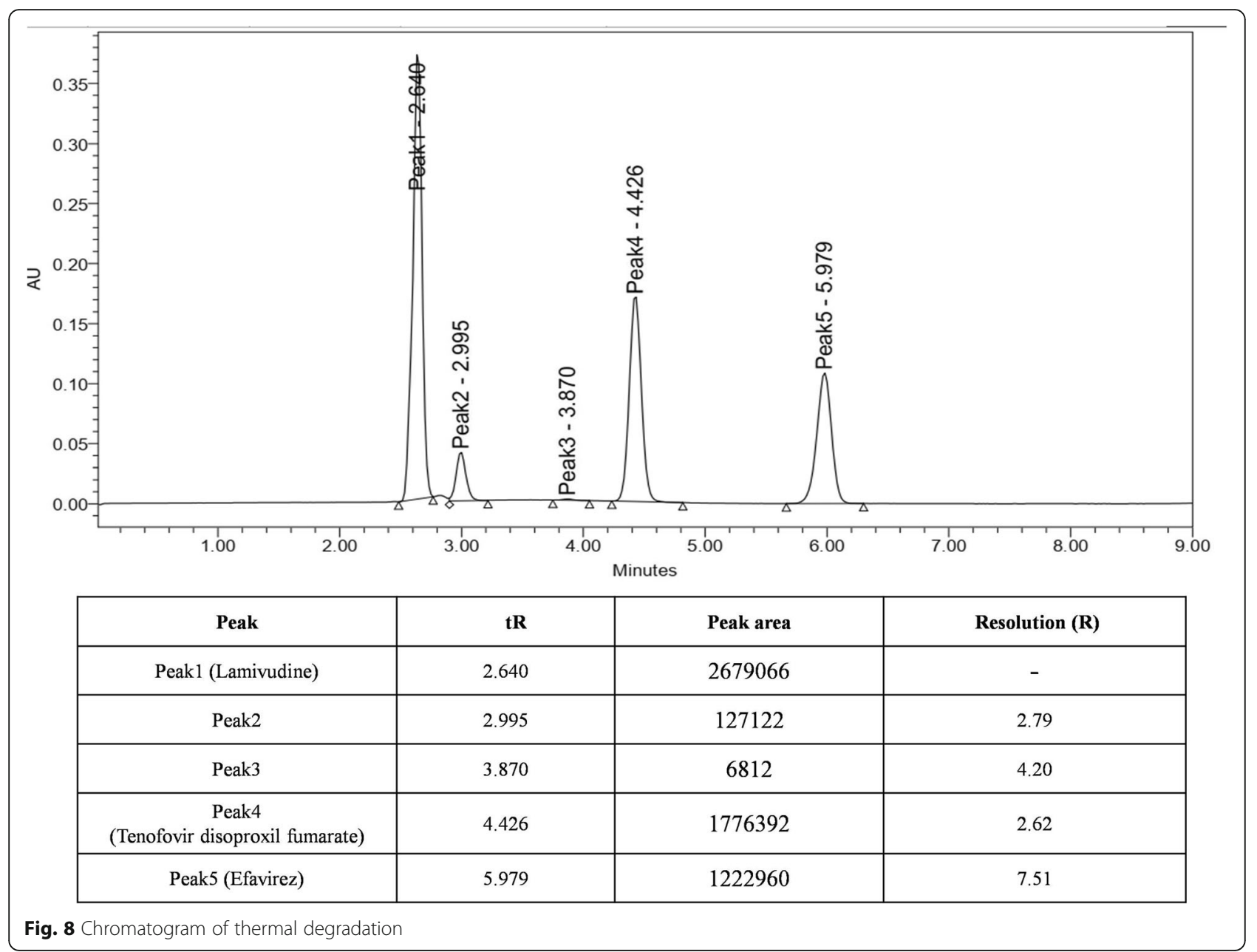

\section{Conclusion}

An easy, accurate, unambiguous, insightful, and precised RP HPLC-PDA method with isocratic mobile phase was created to determine LAM, EVZ, and TDF concurrently in blended powder and their combined tablet. The current method has the ability to separate LAM, EVZ, and TDF, with effective resolution with less retention times. All degradants produced by application of FD degradation were separated with high resolution and determined with good sensitivity that ensures the stability-indicating property of the method. Thus, the projected method has high probability to adopt in the pharmaceutical industrial sector.

Table $\mathbf{8}$ Results of \% assay of the tablet dosage form

\begin{tabular}{lllllll}
\hline Drug & Peak name & Retention time & Peak area & USP tailing & USP plate count & \%Assay \\
\hline LAM & Standard & 2.64 & $2,691,283$ & 1.22 & 2902 & 2993 \\
& Test & 2.65 & $2,690,079$ & 1.21 & 9631 & 99.2 \\
\multirow{2}{*}{ TDF } & Standard & 4.41 & $1,832,027$ & 1.04 & 9057 \\
& Test & 4.40 & $1,831,359$ & 1.04 & 11,737 \\
\multirow{2}{*}{ EVZ } & Standard & 5.964 & $1,217,278$ & 0.94 & 11,261 \\
& Test & 5.903 & $1,217,069$ & 0.94 & \\
\hline
\end{tabular}

Average weight of the tablet, $1520 \mathrm{mg}$

$\%$ Purity of LAMI standard (API), 99.4

$\%$ Purity of TDF standard (API), 99.4

\% Purity of EFV standard (API), 99.3 


\section{Abbreviations}

LAM: Lamivudine; TDF: Tinofovir disproxil fumarate; EVZ: Efavirez; XDB: Extra dense bonding; FD: Forced degradation; SD: Standard deviation; RSD: Relative standard deviation; LOD: Limit of detection; LOQ: Limit of quantification

\section{Acknowledgements}

The authors are also thankful to the Department of pharmaceutical Analysis, GITAM University, Vishakhapatnam, India, for encouragement.

\section{Authors' contributions}

$R G, V K, G S$, and DB contributed equally in design of the work, acquisition and interpretation of data, and manuscript preparation. All authors have read and approved the manuscript.

\section{Funding}

It is self-financed; no funding was sponsored from any organization, funding agency, and non-profit research bodies.

\section{Availability of data and materials}

All data and material should be available upon request.

\section{Declarations}

Ethics approval and consent to participate

Not applicable

\section{Consent for publication}

Not applicable

\section{Competing interests}

The authors declare that they have no competing interests.

\section{Author details}

'Department of Pharmacy, GITAM Deemed to be University, Visakhapatnam, India. ${ }^{2}$ Department of Pharmaceutical Analysis, Bhaskar Pharmacy College, Hyderabad, India. ${ }^{3}$ Department of Pharmaceutical Analysis, MLR Institute of Pharmacy, Hyderabad, India.

Received: 30 July 2020 Accepted: 16 April 2021

Published online: 30 April 2021

\section{References}

1. Avihingsanon A, Maek-a-nantawat W, Gatechompol S, Sapsirisavat V, Thiansanguankul W, Sophonphan J (2017) Efficacy and safety of a oncedaily single-tablet regimen of tenofovir, lamivudine, and efavirenz assessed at 144 weeks among antiretroviral-naïve and experienced HIV-1-infected Thai adults. Int J Infect Dis 1:89-96

2. Wu YS, Zhang WW, Ling XM, Yang L, Huang SB, Wang XC (2016) Efficacy and safety of tenofovir and lamivudine in combination with efavirenz in patients co-infected with human immunodeficiency virus and hepatitis B virus in China. Chin Med J (Engl) 129(3):304-308. https://doi.org/10.4103/03 66-6999.174509

3. More S, Tandulwadkar S, Nikam A, Rathore A, Lohidasan S, Mahadik K (2013) Separation and determination of lamivudine, tenofovir disoproxil fumarate and efavirenz in tablet dosage form by thin-layer chromatographicdensitometric method. J Planar Chromatogr - Mod TLC 26(1):78-85. https:// doi.org/10.1556/JPC.26.2013.1.12

4. Palumbo E (2008) Lamivudine for chronic hepatitis B: a brief review. Braz J Infect Dis 12(5):355-357. https://doi.org/10.1590/s1413-86702008000500002

5. Nadig S, Jacob JT, Bhat I (2013) A stability indicating RP-HPLC method for simultaneous estimation of emtricitabine, tenofovir disoproxil fumarate and efavirenz in pharmaceutical dosage forms. Research J. Pharm. and Tech. 4(391-396):6

6. Badii VS, Buabeng KO, Agyarko Poku T, Forkuo AD, Boamah BB, Arhin SM (2018) Tenofovir-based highly active antiretroviral therapy is associated with superior CD4 T cells repopulation compared to zidovudine-based HAART in HIV 1 infected adults. Int J Chronic Dis. https://www.ncbi.nlm.nih.gov/pmc/a rticles/PMC5932490/
7. Lyseng-Williamson KA, Reynolds NA, Plosker G (2005) Tenofovir disoproxil fumarate: a review of its use in the management of HIV infection. Drugs 65(3):413-432. https://doi.org/10.2165/00003495-200565030-00006

8. Ustianowski A, Arends JE (2015) Tenofovir: what we have learnt after 7.5 million person-years of use. Infect Dis Ther 4(2):145-157. https://doi.org/10.1 007/s40121-015-0070-1

9. Quercia R, Perno C-F, Koteff J, Moore K, McCoig C, St. Clair M (2018) Twentyfive years of lamivudine: current and future use for the treatment of HIV-1 infection. JAcquir Immune Defic Syndr 78(2):125-135. https://doi.org/10.1 097/QAI.0000000000001660

10. Rakhmanina NY, van den Anker JN (2010) Efavirenz in the therapy of HIV infection. Expert Opin Drug Metab Toxicol 6(1):95-103. https://doi.org/10.1 $517 / 17425250903483207$

11. Vrouenraets S, Wit F, Tongeren J, Lange J (2007) Efavirenz: a review. Expert Opin Pharmacother. 8(6):851-871. https://doi.org/10.1517/14656566.8.6.851

12. NNC, AN, Afreen A, Banu AA, PH, Gayathri EJ (2018) Analytical methods for determination of lamivudine and their applicability in biological studies. Res J Pharm Technol 11(11):5166-5172. https://doi.org/10.5958/0974-360X.2018. 00944.7

13. Bhavsar DS, Patel BN, Patel CN (2012) RP-HPLC method for simultaneous estimation of tenofovir disoproxil fumarate, lamivudine, and efavirenz in combined tablet dosage form. Pharm Methods 3(2):73-78. https://doi.org/1 0.4103/2229-4708.103876

14. Anandakumar K, Abirami G, Murugan S, Ashok B (2018) RP-HPLC method for simultaneous estimation of lamivudine, tenofovir disoproxil fumarate and efavirenz in tablet formulation. J Anal Chem 68:815-821

15. Jagadabi V, Nagendra Kumar P, Pamidi S, Ramaprasad L, Nagaraju D (2018) A stability-indicating HPLC method for the determination of potential impurities in a few fixed dose combination of dolutegravir, lamivudine and tenofovir disoproxil fumarate tablets used in the first line treatment of HIV-1 infection. Int Res J Pharm 9(5):65-74. https://doi.org/10.7897/2230-8407. 09575

16. Sharma R, Mehta K (2010) Simultaneous spectrophotometric estimation of tenofovir disoproxil fumarate and lamivudine in three component tablet formulation containing efavirenz. Indian J Pharm Sci 72(4):527-530. https:// doi.org/10.4103/0250-474X.73926

17. Babu C, Devanna N, Reddy KV (2017) Validated gradient stability indicating RP-HPLC method for the simultaneous quantification of 11 related substances in the combined dosage forms of lamivudine and tenofovir disopeoxil fumarate. Int J Appl Pharm 9(4):61-68. https://doi.org/10.22159/ija p.2017v9i4.19001

18. Ramaswamy A, Arul Gnana Dhas AS (2018) Development and validation of analytical method for quantitation of emtricitabine, tenofovir, efavirenz based on HPLC. Arab J Chem 11(2):275-281. https://doi.org/10.1016/j.ara bjc.2014.08.007

19. Mallikarjuna Rao N, Gowri Sankar D (2015) Development and validation of stability-indicating HPLC method for simultaneous determination of lamivudine, tenofovir, and dolutegravir in bulk and their tablet dosage form Future J Pharm Sci. 1(2):73-77. https://doi.org/10.1016/j.fjps.2015.11.002

20. Godela R, G S (2020) An effective stability indicating RP-HPLC method for simultaneous estimation of dolutegravir and lamivudine in bulk and their tablet dosage form. Future J Pharm Sci. 6:9, 1, DOl: https://doi.org/10.1186/ s43094-020-00026-0.

21. Nekkala K (2017) Development and validation for the simultaneous estimation of lamivudine, tenofovir disproxil and dolutegravir in drug product by RP-HPLC. J Pharm Sci 9:6

\section{Publisher's Note}

Springer Nature remains neutral with regard to jurisdictional claims in published maps and institutional affiliations. 